\title{
Application of Multiple Criteria Decision-Making Methods in Assignment Place Selection
}

\author{
Mustafa Soba, ${ }^{1}$ Yusuf Ersoy $\mathbb{D},{ }^{2}$ Ayşenur Tarakcioğlu Altınay, ${ }^{1}$ Birol Erkan, ${ }^{1}$ and Eser Şik ${ }^{3}$ \\ ${ }^{1}$ Faculty of Economics and Administrative Sciences, Uşak University, Bir Eylül Kampüsü, Uşak 64100, Turkey \\ ${ }^{2}$ Scientific Research Projects Coordination Unit, Uşak University, Bir Eylül Kampüsü, Uşak 64100, Turkey \\ ${ }^{3}$ Social Sciences Institute, Uşak University, Bir Eylül Kampüsü, Uşak 64100, Turkey \\ Correspondence should be addressed to Yusuf Ersoy; yusuf.ersoy@usak.edu.tr
}

Received 2 January 2020; Accepted 25 February 2020; Published 30 March 2020

Academic Editor: Przemyslaw Ignaciuk

Copyright (c) 2020 Mustafa Soba et al. This is an open access article distributed under the Creative Commons Attribution License, which permits unrestricted use, distribution, and reproduction in any medium, provided the original work is properly cited.

\begin{abstract}
The aim of this study is to ensure that the location selection of the officers of the personnel class in the Land Forces Command is effective and needs to be met to determine the criteria used in the selection of the place of appointment or which is the most important and to reveal the preference order to the officers making the choice. In this survey, a face-to-face interview technique and 10 subquestionnaires of captain majors were applied. In the questionnaire technique, the weights of the criteria were determined by using the Max100 method, then the values of the criteria were determined by the Max100 method, and the alternatives were graded and ranked by using grey relational analysis (GRA) method and PROMETHEE method which are multicriteria decision-making techniques. As a result of this analysis, the assignment locations are listed and the importance ratings of the criteria used in the selection of the assignment location are determined.
\end{abstract}

\section{Introduction}

The requirement of the personnel officers who serve in the Land Forces Command is provided by the Military Academy and by providing from outside sources. Lieutenants who graduate from the Military Academy and contracted lieutenants who complete basic education make their first assignments after completing one year of class training at class school. The first appointments are made by the lottery system as stated in the Officer Nomination Regulation. Following their first appointment, both officers and noncommissioned officers are assigned to the service garrison in the first years of their occupation, and the staff usually performs this task in the fifth grade garrison. The following policy is to have personnel service in the third or second degree garrison if the staff has not done so. The second, fourth, and fifth garrison duties of the staff officers in the Land Forces Command are usually carried out at the rank of captain major.

The working periods and principles of each garrison are included in the regulation on the appointment of the officer and noncommissioned officers (NCOs). Since all personnel is going to the fourth and fifth garrisons on a certain order basis, appointments are on average aged 6-7 times in the lives of officer and noncommissioned officer, and this figure may be even higher in combat branches. The personnel majors and personnel captains in the Land Forces Command were included in this study. The personnel officers are employed in the headquarters of the Land Forces Command, in the headquarters of the Ministry of National Defense, and a large part in the Military Departments and Military Branches. In this study, 10 officers consisting of personnel, majors, and captains were interviewed and these surveys were conducted in face-to-face interviews. The staff was informed about the work carried out before the surveys were completed.

1.1. Aim of the Study. The purpose of this study is to ensure that the assignment location selections of the personnel class officers working in the Land Forces Command are efficient and that the assignment location selections meet their needs 
and to determine which or which criteria are the most important in the selection of assignment location and to reveal the preference order of the officers who make the choice.

The constraints identified in the study are as follows:

(i) Turkish Statistical Institute (TSI) 2015 life index data were used to calculate the main criteria of security and social opportunities. It should be noted that this data can change because of terrorist incidents recently in Turkey, developing exceptional circumstances in the southern border of Turkey and the migrations from Syria to Turkey.

(ii) Likewise, TSI 2015 life index data were used to calculate the transportation security subcriteria, which is under the main criteria of transportation. It should be remembered that these data also can change due to developments in the region.

(iii) Besides, according to the Max100 method, it was determined that the officers who scored the main criteria and subcriteria scored according to the information obtained from the Internet and social media and only by calling the personnel working there by phone. Generally, officers have not been in alternative areas, and they scored according to the information obtained about the region.

1.2. Determination of Criteria. The criteria used in this study were prepared by taking the opinions of 10 officers from the personnel branch in the rank of colonel and sublieutenant.

Few studies have been found in the literature search on the selection of the place of appointment. One of the studies is a study on the selection of teachers' assignments. To determine the importance of the criteria, the AHP method was used to make the provincial rankings and the preferences of a teacher who was in his hometown Kirikkale were listed [1].

The purpose of another study is to put the planning of the appointments of the Gendarmerie Commands assigned to the order of the Gendarmerie Commander based on more objective foundations and thus help the decision-makers to make the best decisions and to create a decision support system [2]. The study was carried out by the AHP method and eight criteria were taken as a basis. In 2002, the assignment data of Istanbul Provincial Gendarmerie Command were used. As a result, the appointment of the Gendarmerie NCOs appointed to the order of the Provincial Gendarmerie Command was made more objectively. In this study, we used the subcriteria, which we did cowork, child and school status.

In the study, the criteria to be used by the personnel branch officers in the selection of the place of appointment were determined by the face-to-face interview technique, which was conducted by 10 officers with ranks between the first and second rank. The criteria which were determined as 5 items are "family situations," "transportation," "duty and its features," "security," and "social facilities."

(a) Considering the family criteria, factors such as the ability to be assigned to the same place if the spouse is employed, the school status of the children, and the presence of a nursery for young children are considered as subcriteria. These are "the status of being assigned to the same place in case of spousal work," "school status of children," and "nursery status for young children."

(b) While the transportation criteria are taken into consideration, the distance to the airport, transportation security by road, and proximity to the country are taken into consideration as subcriteria. These are "distance to airport," "transportation security," and "proximity to hometown."

(c) While the criteria of duty and characteristics are taken into consideration, the elements such as housing status, attitudes and behaviors of superiors, and current/squad status are taken into consideration as subcriteria. These are "housing status," "attitudes and behaviors of supervisors," and "current/squad status."

(d) For the security criteria, the life index published in 2016 and prepared by TSI was taken as the basis. The index of life in provinces is an index study to measure, compare, and monitor the life of individuals and households at the local level in the distinction of life dimensions using objective and subjective criteria [3]. While preparing this index, 11 dimensions were taken into consideration and a total of 41 indicators were taken as a basis for 11 dimensions.

(e) For the criteria of social facilities published in 2016 and prepared by TSI, the life index is taken as the basis.

1.3. Alternatives. The alternatives used in this study consisted of the fourth regional garrison. In 2018, garrisons were discharged based on an appointment. Assignment garrisons, which are the basis of the study, are the garrison where the staff majors and staff captain may choose, and the alternatives used in the study are shown in Table 1 . A total of 6 alternatives were used in the study.

As a result, the hierarchical structure formed by the research, which is carried out to rank the appointment preferences of the officers in the personnel class majorcaptain rankings who are working within the Land Forces Command in the most effective and in line with the requirements, is shown in Figure 1.

\section{Literature Review}

There are many studies in the literature using multicriteria decision-making methods [4-8]. There are many studies in the literature using the grey relational analysis (GRA) method and the PROMETHEE method [5].

Some of the studies in the literature using the grey relational analysis method are as follows. Satapathy et al. have used the GRA method for assessment of fiber contribution to friction material performance [9]. Hui and Bifeng have used 
TABLE 1: Staff class empty and empty list of garrisons (personnel major-captain) based on 2018 assignment planning.

\begin{tabular}{lcc}
\hline Province/County & Major & Captain \\
\hline Bingol & $\mathbf{X}$ & $\mathbf{X}$ \\
Bitlis Tatvan & & $\mathbf{X}$ \\
Kars Sarıkamış & $\mathbf{X}$ & \\
Mardin & $\mathbf{X}$ & $\mathbf{X}$ \\
Şanliurfa Siverek & & \\
Van Erciş & & \\
\hline
\end{tabular}

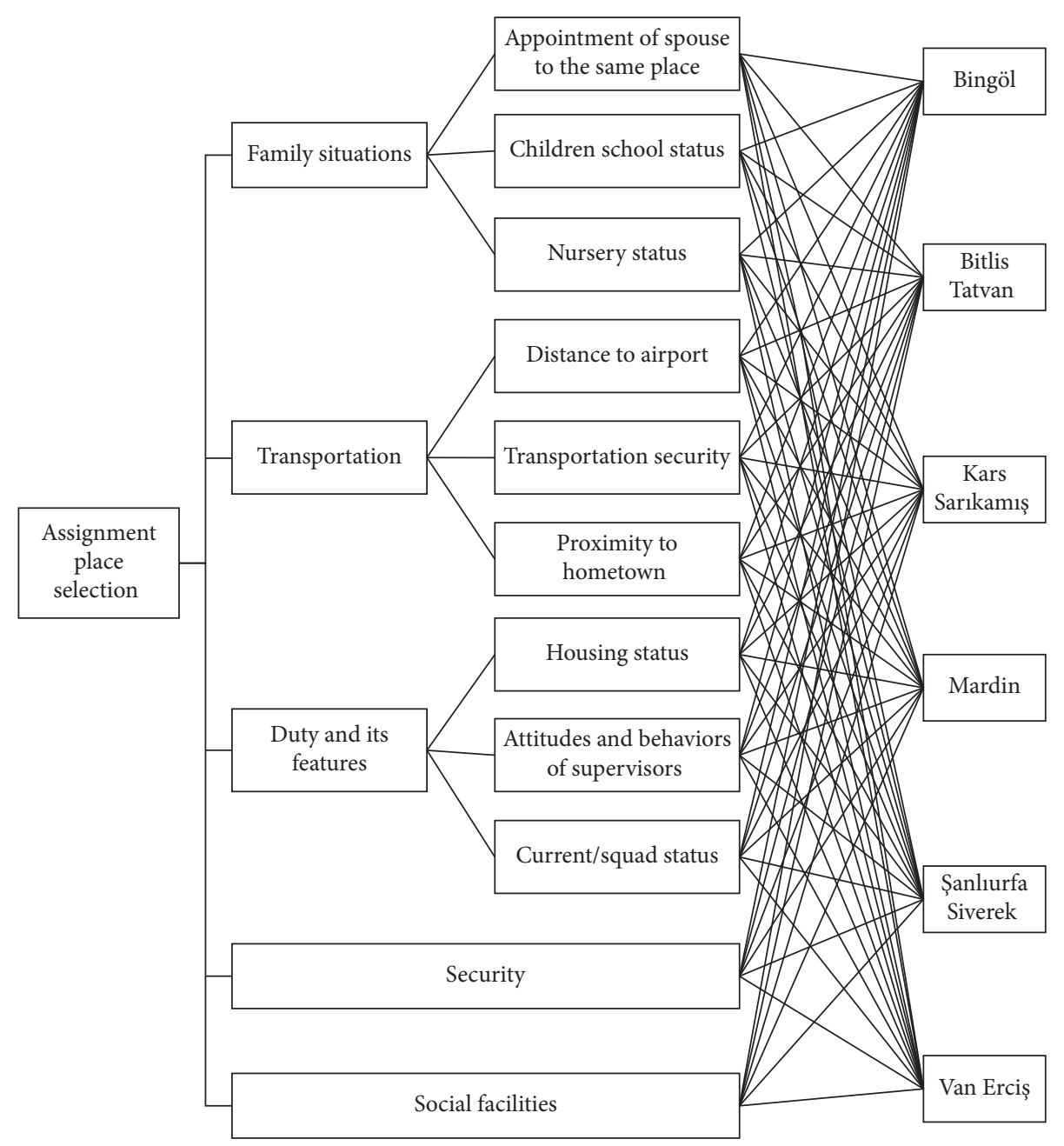

FIGURE 1: Hierarchical structure of the research.

GRA and TOPSIS for efficiency evaluation of weapon systems [10]. In the study of Ozdemir and Deste, the performance evaluation problem for 82 suppliers of a company operating in the automotive sector has been examined and the problem has been handled by the GRA method [11]. In the research of Peker and Baki, three companies operating in the insurance sector are listed according to their financial performance by using the GRA method. As a result, it can be concluded that the financial performance of a company with high liquidity ratios may be high [12]. In the study of Kose et al., GRA and Grey Analytical Network Process (GANP) were used together and the personnel selection problem was discussed for an institution providing training services. The results were valid and consistent [13]. The study of Sisman and Eleren presented qualitative features such as model year, model distance, price, fuel consumption, baggage size, performance and motor power, fuel system, transmission type, and color. Both the ELECTRE and the grey relational analysis were investigated with MCDM methods. The results obtained from the two methods were different [14]. Jayant has used GRA, VIKOR, and TOPSIS methods together for a selection of most appropriate warehouse location in a manufacturing organization [15]. Kundakc1 has used the GRA method to select the most appropriate software engineer in a technology firm [16]. Wu et al. have used the GRA and hybrid entropy-based weighting methods for the 
comprehensive evaluation of coal-fired power units [17]. Parhizgarsharif et al. have used a new hybrid framework based on Best Worst Method (BWM), GRA, and VIKOR methods in order to rank the potential site layout locations by consideration of the cost and safety criteria in the Mehr Construction Project in Tehran, Iran [18].

Some of the studies in the literature using the PROMETHEE method are as follows. Albadvi has used the PROMETHEE method on strategic selection for application flagships [19]. Albadvi et al. have used the PROMETHEE method for stock trading assessment [20]. Beynon and Wells have used the PROMETHEE method for lean improvement in chemical emissions [21]. Chen et al. have used the PROMETHEE method for the ranking of logistic suppliers [22]. In the research of Akkaya and Demireli, the means of public disclosure of a public company that decided to make public offerings were examined in terms of cost, accessibility, efficiency, and image criteria and the PROMETHEE method was used. As a result of the study, it has been concluded that public announcements will be more effective in terms of economic growth and television broadcasting in the periods of economic contraction [23]. The study of Yilmaz and Dagdeviren examined the selection of a welding machine based on the criteria defined by the linguistic expression of the criteria defined by multicriteria decision-making [24]. Ishizaka and Nemery have selected statistical distribution by using the PROMETHEE method [25]. In the study of Soba, the PROMETHEE method has been applied by using price, fuel, maximum speed, safety, horsepower, and performance criteria for the selection of six different panel cars in the same class. As a result of the study, the best car was Ford Transit Connect Combi [26]. Vetschara and De Almeida have used the PROMETHEE method for solving the problem in the selection of portfolio [27]. Sakarya and Aytekin have measured the financial performance of the banks traded on the Istanbul Stock Exchange (ISE) with the help of financial ratios between 2007 and 2011 and the performance results obtained by stock returns but could not reach a meaningful conclusion [28]. Govindan et al. have used a hybrid multicriteria decision-making model combining DEMATEL based on ANP (DANP) with the PROMETHEE for selecting the best green manufacturing practices based on dimensions and relevant criteria [29]. Bottero et al. have used PROMETHEE method, SWOT Analysis, and Stakeholders Analysis for the evaluation of alternative renewal strategies of an urban area in Northern Italy [30].

\section{Method}

Multicriteria decision-making (MCDM) studies aim to reach an optimal solution by using computer-aided processes to make various decisions that are likely to be encountered in real life [23]. MCDM methods are the methods used to evaluate multiple criteria and to choose the ideal one among the alternatives. MCDM methods are applied in choice, classification, or sorting problems in daily life. There are methods such as AHP, AAP, ELECTRE, PROMETHEE, TOPSIS, VIKOR, SAW, and GIA [5, 31-33]. Grey relational analysis (GRA) and PROMETHEE methods were used in this study. However, in this study, the Max100 method was used to find criteria weights and to create decision matrices. The resulting criterion weights and decision matrices are standardized by the standardization step used in the grey relational analysis method. The reason for this process is that some of the criteria in the decision matrix used in the study are better than the minimum and the units of values used are different. As a result, the GRA method standardization procedure was applied to each decision maker's decision matrix and GRA and PROMETHEE methods were applied to the standardized decision matrices obtained and the decision preferences of each decision maker were listed.

3.1. Max100 Method. In the Max100 method, if the alternative is the most important for that criteria, by considering specific criteria, 100 points are given to that alternative or more than one alternative. Based on the same criterion, other alternatives also take a value of 0-99 at the best alternative/alternative ratio.

The Max100 method described in [34, 35] is a more reliable method [36]. Bottomley and Doyle compared the method of direct grading with two different methods (Max100 and Min10) in their study [34]. Max100 and direct grading methods were found to be more reliable than the Min10 method. Max100 method was used in grading the criteria used in the selection of the place of selection and in determining the weights of each criteria and subcriteria.

3.2. Grey Relational Analysis (GRA) Method. Grey relational analysis, which is one of the methods of MCDM, was introduced into the literature by Professor Deng Ju-long under the name Grey System Theory. GRA is a method of determining the relationship between the reference series compared to each factor [37]. The grey relational degree used in grey relational analysis indicates the degree of impact between the criteria. The most important feature that differentiates it from other MCDM methods is the use of reference series in the research. In the reference series, the smallest or largest values taken by the criterion can be used and ideal values can also be used [38].

The results obtained to find the best alternative in the grey relational analysis should be comparable. This process is called grey relational formation, where the results obtained for each criterion and alternative should be comparable. Then, the reference series which distinguishes grey relational analysis from other MCDM methods and which is the most prominent feature of this method is determined. The grey correlation coefficient is then determined, and the grey relational coefficient between the reference series and each comparable series is calculated based on the grey relational coefficients [11].

Grey relational analysis is usually applied in six steps as follows [14, 38, 39].

First step (formation of a decision matrix): the decision matrix showing the values taken by the alternatives for each criteria is formed. $N$ is alternative, and $m$ is criteria decision matrix: 


$$
x_{i j}=\left[\begin{array}{cccc}
x_{1}(1) & x_{1}(2) & \ldots & x_{1}(m) \\
x_{2}(1) & x_{2}(2) & \ldots & x_{2}(m) \\
\vdots & \vdots & \ddots & \vdots \\
x_{n}(1) & x_{n}(2) & \ldots & x_{n}(m)
\end{array}\right], \quad i=1, \ldots, n
$$

Second step (standardization): since different units are used in the measurement of the criteria, it has to be standardized to compare the criteria. In the standardization phase, there are three different situations where the higher is better, the lower is better, and the ideal is better. The equations to be used in these cases are as follows [40]:

$$
\begin{aligned}
& x_{i}^{\prime}(j)=\frac{x_{i}(j)-\min _{i=1}^{n} x_{i}(j)}{\max _{i=1}^{n}(j)-\min _{i=1}^{n} x_{i}(j)}, \quad \text { (if the great value is better), } \\
& x_{i}^{\prime}(j)=\frac{\max _{i=1}^{n} x_{i}(j)-x_{i}(j)}{\max _{i=1}^{n} x_{i}(j)-\min _{i=1}^{n} x_{i}(j)}, \quad \text { (if the small value is better), } \\
& x_{i}^{\prime}(j)=1-\frac{\left|x_{i}(j)-x_{i d l}(j)\right|}{\max \left\{\max _{i=1}^{n} x_{i}(j)-x_{i d l}(j), x_{i d l}(j)-\min _{i=1}^{n} x_{i}(j)\right\}}, \quad \text { (if the ideal value is better). }
\end{aligned}
$$

Once this is done, the standardized values are $0-1$ and the maximum value for each criterion is the best alternative.
Step three (establishing the standardized decision matrix and reference series):

$$
x_{i j}^{\prime}=\left[\begin{array}{cccc}
x_{1}^{\prime}(1) & x_{1}^{\prime}(2) & \ldots & x_{1}^{\prime}(m) \\
x_{2}^{\prime}(1) & x_{2}^{\prime}(2) & \ldots & x_{2}^{\prime}(m) \\
\vdots & \vdots & \ddots & \vdots \\
x_{n}^{\prime}(1) & x_{n}^{\prime}(2) & \ldots & x_{n}^{\prime}(m)
\end{array}\right] \quad i=1, \ldots, n j=1, \ldots, m
$$

When creating the reference series, the largest values in each column of the decision matrix where the standardization process is applied are used:

$x_{0}^{\prime}=x_{0}^{\prime}(1), x_{0}^{\prime}(2), \ldots, x_{0}^{\prime}(m)$.
Step four (creation of the difference matrix): when creating the difference matrix, the standardization obtained in the previous step is obtained by subtracting the reference series from the decision matrix:

$$
\begin{aligned}
\Delta_{0 i}(j) & =\left|x_{0}^{\prime}(j)-x_{i}^{\prime}(j)\right|, \\
\Delta_{i j} & =\left[\begin{array}{cccc}
\Delta_{01}(1) & \Delta_{01}(2) & \ldots & \Delta_{01}(m) \\
\Delta_{02}(1) & \Delta_{02}(2) & \ldots & \Delta_{02}(m) \\
\vdots & \vdots & \ddots & \vdots \\
\Delta_{0 n}(1) & \Delta_{0 n}(2) & \ldots & \Delta_{0 n}(m)
\end{array}\right], \quad i=1, \ldots, n \quad j=1, \ldots, m .
\end{aligned}
$$

Step five (calculation of grey relational coefficients):

$\gamma_{0 i}(j)=\frac{\min _{i=1}^{n} \min _{j=1}^{m} \Delta_{0 i}(j)+\xi \times \max _{i=1}^{n} \max _{j=1}^{m} \Delta_{0 i}(j)}{\Delta_{0 i}(j)+\xi \times \max _{i=1}^{n} \max _{j=1}^{m} \Delta_{0 i}(j)}$, where $\xi$ is a coefficient that takes a value between 0 and 1 and is usually taken as 0.5 .

Step six (calculation of the grey relationship degree): the grey correlation coefficients obtained in the previous step are multiplied by the weight of the criteria, 
and the grey relationship degree is obtained when it is collected for each alternative.

$$
\Gamma_{0 i}=\sum_{j=1}^{m} w(j) \gamma_{0 i}(j), \quad \sum_{j=1}^{m} w(j)=1 .
$$

In this step, $w(j), j$ indicates the weight of the criteria. When the results obtained for each alternative are sorted from large to small, a sequence from best to worst is obtained.

3.3. PROMETHEE Method. PROMETHEE was first used in a conference held in Quebec, Canada, in 1982 and developed by Jean-Pierre Brans. PROMETHEE is a sorting method that is quite simple in concept and application compared to other methods for multicriteria analysis [41].

It was used for two purposes when it was used for the first time, while in PROMETHEE I, the objective was the partial order of alternatives, while the goal in PROMETHEE II was the exact ranking of alternatives [42]. After a very short period, it is aimed to rank based on intervals with PROMETHEE III, to make a ranking for continuous situations with PROMETHEE IV, to make a sequence that includes partition constraints with PROMETHEE $\mathrm{V}$, and to represent the human brain with PROMETHEE VI. These versions were also developed by Brans and Mareschal. With this method, the alternatives in any decision problem are evaluated according to the preference functions determined by the researcher, and the researcher partially and fully lists the alternatives used in the research by making a binary comparison $[26,43]$.

The researcher using this method needs two different information. The weight of the criteria (the sum of the weights must be equal to 1) and the preference function to be used for each criterion should be determined. In the study a $P$, preference function, is determined. This value shows the difference between two decision points (alternative) such as $a$ and $b$ based on certain criteria.

The PROMETHEE method, which is used for sorting purposes within the MCDM methods, is simple, clear, and stable. Generally, the concept establishes the relationship between the variables $[44,45]$. The steps to be followed in the PROMETHEE method are as follows $[26,28,46]$ :

(i) Determining the criteria and criteria weights of the researcher's alternatives

(ii) Determining the preference functions of the researcher

(iii) Identifying common preference functions and preference indexes

(iv) Calculating positive and negative superiority values

(v) Obtaining a partial order of alternatives with PROMETHEE I

(vi) Calculating net priority values

(vii) With PROMETHEE II, obtaining the exact order of alternatives

The PROMETHEE method is based on pairwise comparisons. Thus situated, the deviation between the assessments of two alternatives on certain criteria is considered. For small deviations, the decision-maker will allocate a small preference to the best alternative. The larger the deviation, the larger the preference. There is no objection taking into account that these preferences are real number varying between 0 and 1 . The preference function is expressed as $P_{k}(a, b)$. The preference function takes values between 0 and 1 as shown in [46].

$$
0 \leq P_{k}(a, b) \leq 1
$$

If a criterion is maximized, this function is giving the preference of $a$ over $b$ for observed deviations between their evaluations on criteria $g_{k}(\cdot)$. The preferences equal " 0 " when the deviations are negative. The following features apply [46]:

$$
P_{k}(a, b)>0 \Rightarrow P_{k}(b, a)=0 \text {, }
$$

where the pair $\left\{g_{k}, P_{k}(a, b)\right\}$ is called the generalised criterion associated with criteria $g_{k}(\cdot)$. Such generalised criteria have to be defined for each criterion [46].

The PROMETHEE method uses 6 different preference functions [26, 44, 46-48]. Types of generalised criteria $\left(P_{k}(d)\right.$ : preference function) are as follows [44, 46-48]:

1st type (ordinary type) preference function: if the researcher does not have any preference for the criteria used, the function used in this case is the 1st type (usual type) function:

$$
P_{k}(d)= \begin{cases}0 & d \leq 0 \\ 1 & d>0\end{cases}
$$

2nd type ( $U$ type) preference function: in case the researcher chooses alternatives with a value larger than a certain value for any criteria, the function for which the criterion can be used is the second type (type $U$ ) preference function:

$$
P_{k}(d)= \begin{cases}0, & d \leq q_{k} \\ 1, & d>q_{k}\end{cases}
$$

3rd type ( $\mathrm{V}$ type) preference function: the researcher chooses alternatives with a value greater than a certain value for any criteria, but he may be considering using alternatives other than his preference which are below a certain value. In this case, the function that can be used for that criterion is type 3 ( $\mathrm{V}$ type):

$$
P_{k}(d)= \begin{cases}0, & d \leq 0, \\ \frac{d}{p}, & 0 \leq d \leq p \\ 1, & d>p .\end{cases}
$$

4th type (level) preference function: if the researcher chooses alternatives with values in a certain range for 
TABLE 2: Calculation method of criteria and subcriteria.

\begin{tabular}{|c|c|c|}
\hline Criteria & Subcriteria & Calculation method \\
\hline \multirow{3}{*}{ Family situations } & Appointment of spouse & It was determined by the Max100 method \\
\hline & Children school status & $\begin{array}{c}\text { The number of schools in each alternative is based on the schools' link at the } \\
\text { institutional address of the Ministry of National Education }\end{array}$ \\
\hline & Nursery status & $\begin{array}{l}\text { Internet researches and the data obtained from the personnel working in that region } \\
\text { were taken into consideration and the number of nursery schools was taken as a basis }\end{array}$ \\
\hline \multirow{3}{*}{ Transportation } & Distance to airport & In google maps, the alternative is based on the distance to the nearest airport \\
\hline & Transportation security & $\begin{array}{l}\text { The average of the security values of the provinces on the fastest way from the country to } \\
\text { the alternative in the TSI's } 2015 \text { life index was taken }\end{array}$ \\
\hline & Proximity to hometown & Google maps is based on the fastest route from home to the alternative \\
\hline \multirow{3}{*}{$\begin{array}{l}\text { Duties and } \\
\text { features }\end{array}$} & Housing status & It was determined by the Max100 method \\
\hline & $\begin{array}{l}\text { Attitudes and behaviors of } \\
\text { supervisors }\end{array}$ & It was determined by the Max100 method \\
\hline & Current/squad status & Available personnel/squad ratio is used \\
\hline & Security & TSI was obtained from the 2015 life index data \\
\hline & Social facilities & TSI was obtained from the 2015 life index data \\
\hline
\end{tabular}

any criteria, the function for which the criteria can be used is the 4 th type (level) preference function:

$$
P_{k}(d)= \begin{cases}0, & d \leq q_{k}, \\ \frac{1}{2}, & q_{k} \leq d \leq p_{k}, \\ 1, & d>p_{k} .\end{cases}
$$

5th type (linear) preference function: in case the researcher chooses one of the alternatives with a value greater than the average value for any criteria, the function for which the criterion can be used is the 5 th (linear) preference function:

$$
P_{k}(d)= \begin{cases}0, & d \leq q_{k}, \\ \frac{d-q_{k}}{p_{k}-q_{k}}, & q_{k} \leq d \leq p_{k} \\ 1, & d>p_{k} .\end{cases}
$$

6th type (Gaussian) preference function: in case the researcher chooses the alternatives by considering the deviation values from the average for any criteria, the function that can be used for that criteria is the sixth type (Gaussian) preference function:

$$
P_{k}(d)= \begin{cases}0, & d \leq 0, \\ 1-e^{\left(d^{2} / 2 s_{k}^{2}\right),} & d>0 .\end{cases}
$$

In each case, 0,1 , or 2 parameters have to be defined, and their significance is clear: $q$ is a threshold or indifference; $p$ is a threshold or strict preference; $s$ is an intermediate value between $q$ and $p$.

The calculations used in the PROMETHEE method are as follows [44, 46-48]: (i) The formula used when calculating preference indices; $\pi(a, b)=\sum w_{k} p_{k}(a, b)$

(ii) The formula used when calculating positive superiority; $\varphi^{+}(a)=\sum \pi((a, b) /(n-1))$

(iii) The formula used when calculating the negative superiority; $\varphi^{-}(a)=\sum \pi(a, b) /(n-1)$

(iv) The formula used when calculating the net priority value; $\varphi(a)=\varphi^{+}(a)-\varphi^{-}(a)$

3.4. Establishing the Decision Matrix. The criteria used in the study were obtained by face-to-face interviews with officers in colonel-captain rankings. How the values of the criteria and subcriteria are obtained can be seen from Table 2 .

\section{Results}

4.1. Determination of Weights. This study was prepared by surveying 10 officers in the captain-major ranks, and firstly the weights of each criterion and subcriteria were determined. Max100 method was used to determine the weights. According to the Max100 method, participants were asked to give a score of 100 points to the ones that are the most important in the research and to give a score of 0-99 according to the severity level of the other criteria. The same method was used to determine the weight of the subcriteria of the first criterion. The arithmetic averages of the 10 questionnaires were taken and the weights of the criteria and subcriteria were shown in Table 3 .

As shown in Table 3, the weights of the main criteria vary between 0.23 and 0.18 , and no significant difference was found between them. Each main criterion is of sufficient importance for the subject studied. According to the results, the main criterion with the highest weight is the safety criterion. The weight of the security criterion is $23 \%$. The safety criteria were followed by family conditions, transportation with $19 \%$, social facilities with $19 \%$ and $18 \%$ by weight, and the criteria of duties and characteristics, respectively. As the alternatives used in the study were eastern and southeastern provinces of Turkey and 
TABLE 3: Determining the weights of criteria and subcriteria.

\begin{tabular}{|c|c|c|c|}
\hline \multicolumn{4}{|c|}{ Choice of determination } \\
\hline Criteria & Weights & Subcriteria & Weights \\
\hline Family situations & 0.21 & $\begin{array}{l}\text { Appointment of spouse } \\
\text { Children school status } \\
\text { Nursery status }\end{array}$ & $\begin{array}{l}0.35 \\
0.36 \\
0.29\end{array}$ \\
\hline Transportation & 0.19 & $\begin{array}{c}\text { Distance to airport } \\
\text { Transportation security } \\
\text { Proximity to hometown }\end{array}$ & $\begin{array}{l}0.37 \\
0.35 \\
0.28\end{array}$ \\
\hline Duties and features & 0.18 & $\begin{array}{c}\text { Housing status } \\
\text { Attitudes and behaviors of supervisors } \\
\text { Current/squad status }\end{array}$ & $\begin{array}{l}0.36 \\
0.33 \\
0.32\end{array}$ \\
\hline $\begin{array}{l}\text { Security } \\
\text { Social facilities }\end{array}$ & $\begin{array}{l}0.23 \\
0.19\end{array}$ & & \\
\hline
\end{tabular}

TABle 4: Decision matrix (results of 1st officer).

\begin{tabular}{|c|c|c|c|c|c|c|c|c|c|c|c|}
\hline & \multicolumn{3}{|c|}{ Family situations } & \multicolumn{3}{|c|}{ Transportation } & \multicolumn{3}{|c|}{ Duties and features } & \multirow{2}{*}{ Security } & \multirow{2}{*}{ Social facilities } \\
\hline & SC11 & SC12 & SC13 & SC21 & SC22 & SC23 & SC31 & SC32 & SC33 & & \\
\hline Bingöl & 100 & 147 & 10 & 10 & 0.6573 & 745 & 80 & 100 & 1 & 0.7017 & 0.3457 \\
\hline Bitlis Tatvan & 100 & 84 & 2 & 77 & 0.6459 & 934 & 100 & 100 & 0.8 & 0.6253 & 0.3491 \\
\hline Kars Sarıkamış & 90 & 116 & 1 & 56 & 0.6779 & 814 & 70 & 90 & 1.33 & 0.5982 & 0.2675 \\
\hline Mardin & 100 & 171 & 4 & 27 & 0.6418 & 844 & 100 & 100 & 1.00 & 0.6496 & 0.1965 \\
\hline Şanlıurfa Siverek & 90 & 260 & 3 & 84 & 0.6402 & 647 & 80 & 100 & 0.78 & 0.6626 & 0.2988 \\
\hline Van Erciş & 90 & 213 & 2 & 105 & 0.6497 & 937 & 80 & 100 & 0.50 & 0.5391 & 0.3388 \\
\hline
\end{tabular}

Table 5: Standardized decision matrix (results of 1st officer).

\begin{tabular}{|c|c|c|c|c|c|c|c|c|c|c|c|}
\hline & \multicolumn{3}{|c|}{ Family situations } & \multicolumn{3}{|c|}{ Transportation } & \multicolumn{3}{|c|}{ Duties and features } & \multirow[b]{2}{*}{$\begin{array}{c}\text { Security } \\
\text { Max }\end{array}$} & \multirow[b]{2}{*}{$\begin{array}{c}\text { Social facilities } \\
\text { Max }\end{array}$} \\
\hline & $\begin{array}{l}\text { SC11 } \\
\text { Max }\end{array}$ & $\begin{array}{l}\text { SC12 } \\
\text { Max }\end{array}$ & $\begin{array}{l}\text { SC13 } \\
\text { Max }\end{array}$ & $\begin{array}{l}\text { SC21 } \\
\text { Min }\end{array}$ & $\begin{array}{l}\text { SC22 } \\
\text { Max }\end{array}$ & $\begin{array}{l}\text { SC23 } \\
\text { Min }\end{array}$ & $\begin{array}{l}\text { SC31 } \\
\text { Max }\end{array}$ & $\begin{array}{l}\text { SC32 } \\
\text { Max }\end{array}$ & $\begin{array}{l}\text { SC33 } \\
\text { Max }\end{array}$ & & \\
\hline Bingöl & 1.00 & 0.36 & 1.00 & 1.00 & 0.45 & 0.66 & 0.33 & 1.00 & 0.60 & 1.00 & 0.98 \\
\hline Bitlis Tatvan & 1.00 & 0.00 & 0.11 & 0.29 & 0.15 & 0.01 & 1.00 & 1.00 & 0.36 & 0.53 & 1.00 \\
\hline Kars Sarıkamış & 0.00 & 0.18 & 0.00 & 0.52 & 1.00 & 0.42 & 0.00 & 0.00 & 1.00 & 0.36 & 0.47 \\
\hline Mardin & 1.00 & 0.49 & 0.33 & 0.82 & 0.04 & 0.32 & 1.00 & 1.00 & 0.60 & 0.68 & 0.00 \\
\hline Şanlıurfa Siverek & 0.00 & 1.00 & 0.22 & 0.22 & 0.00 & 1.00 & 0.33 & 1.00 & 0.33 & 0.76 & 0.67 \\
\hline Van Erciş & 0.00 & 0.73 & 0.11 & 0.00 & 0.25 & 0.00 & 0.33 & 1.00 & 0.00 & 0.00 & 0.93 \\
\hline Reference & 1 & 1 & 1 & 1 & 1 & 1 & 1 & 1 & 1 & 1 & 1 \\
\hline
\end{tabular}

TABle 6: Difference matrix (results of 1st officer).

\begin{tabular}{lccccccccccc}
\hline & \multicolumn{3}{c}{ Family situations } & \multicolumn{3}{c}{ Transportation } & \multicolumn{3}{c}{ Duties and features } & \multirow{2}{*}{ Security } & Social facilities \\
& SC11 & SC12 & SC13 & SC21 & SC22 & SC23 & SC31 & SC32 & SC33 & \\
\hline Bingöl & 0.00 & 0.64 & 0.00 & 0.00 & 0.55 & 0.34 & 0.67 & 0.00 & 0.40 & 0.00 & 0.02 \\
Bitlis Tatvan & 0.00 & 1.00 & 0.89 & 0.71 & 0.85 & 0.99 & 0.00 & 0.00 & 0.64 & 0.47 & 0.00 \\
Kars Sarıkamış & 1.00 & 0.82 & 1.00 & 0.48 & 0.00 & 0.58 & 1.00 & 1.00 & 0.00 & 0.64 & 0.53 \\
Mardin & 0.00 & 0.51 & 0.67 & 0.18 & 0.96 & 0.68 & 0.00 & 0.00 & 0.40 & 0.32 & 1.00 \\
Şanliurfa Siverek & 1.00 & 0.00 & 0.78 & 0.78 & 1.00 & 0.00 & 0.67 & 0.00 & 0.67 & 0.24 & 0.33 \\
Van Erciş & 1.00 & 0.27 & 0.89 & 1.00 & 0.75 & 1.00 & 0.67 & 0.00 & 1.00 & 1.00 & 0.07 \\
\hline
\end{tabular}

due to recent terror incidents, the safety criteria are higher compared to the other criteria.

The distribution within the subcriteria is almost equal. The child school status criteria in the family status criteria is $36 \%$ higher than other subcriteria. In the same way, the transport criteria, which is within the transportation criteria, has the highest ratio with $37 \%$. The proximity to the country seems to have lost its importance thanks to the developing technology and airports in almost every province of the country. There was no significant difference between the subcriteria in the criteria of tasks and characteristics. The subcriterion of residence status has the highest rate of $36 \%$. 
TABLE 7: Grey relational coefficients (results of 1st officer unweighted).

\begin{tabular}{|c|c|c|c|c|c|c|c|c|c|c|c|c|c|}
\hline & \multicolumn{3}{|c|}{ Family situations } & \multicolumn{3}{|c|}{ Transportation } & \multicolumn{3}{|c|}{ Duties and features } & \multirow{2}{*}{ Security } & \multirow{2}{*}{ Social facilities } & \multirow{2}{*}{ Average } & \multirow{2}{*}{ Ranking } \\
\hline & SC11 & SC12 & SC13 & SC21 & SC22 & SC23 & SC31 & SC32 & SC33 & & & & \\
\hline Bingöl & 1.00 & 0.44 & 1.00 & 1.00 & 0.48 & 0.60 & 0.43 & 1.00 & 0.56 & 1.00 & 0.96 & 0.77 & 1 \\
\hline Bitlis Tatvan & 1.00 & 0.33 & 0.36 & 0.41 & 0.37 & 0.34 & 1.00 & 1.00 & 0.44 & 0.52 & 1.00 & 0.62 & 3 \\
\hline Kars Sarıkamış & 0.33 & 0.38 & 0.33 & 0.51 & 1.00 & 0.46 & 0.33 & 0.33 & 1.00 & 0.44 & 0.48 & 0.51 & 5 \\
\hline Mardin & 1.00 & 0.50 & 0.43 & 0.74 & 0.34 & 0.42 & 1.00 & 1.00 & 0.56 & 0.61 & 0.33 & 0.63 & 2 \\
\hline Şanlıurfa Siverek & 0.33 & 1.00 & 0.39 & 0.39 & 0.33 & 1.00 & 0.43 & 1.00 & 0.43 & 0.68 & 0.60 & 0.60 & 4 \\
\hline Van Erciş & 0.33 & 0.65 & 0.36 & 0.33 & 0.40 & 0.33 & 0.43 & 1.00 & 0.33 & 0.33 & 0.88 & 0.49 & 6 \\
\hline L MAX & 1.00 & & & & & & & & & & & & \\
\hline $\mathrm{L}$ min & 0.00 & & & & & & & & & & & & \\
\hline$\zeta(\mathrm{KSI})$ & 0.5 & & & & & & & & & & & & \\
\hline
\end{tabular}

TABLE 8: Calculation of the GRD (results of the 1st officer).

\begin{tabular}{|c|c|c|c|c|c|c|c|c|c|c|c|c|c|}
\hline & \multicolumn{3}{|c|}{ Family situations } & \multicolumn{3}{|c|}{ Transportation } & \multicolumn{3}{|c|}{ Duties and features } & \multirow{2}{*}{ Security } & \multirow{2}{*}{ Social facilities } & \multirow{2}{*}{ Average } & \multirow{2}{*}{ Ranking } \\
\hline & SC11 & SC12 & SC13 & SC21 & SC22 & SC23 & SC31 & SC32 & SC33 & & & & \\
\hline Wİ & 0.3488 & $\begin{array}{l}0.2145 \\
0.3566\end{array}$ & 0.2946 & 0.3704 & $\begin{array}{l}0.1855 \\
0.3539\end{array}$ & 0.2757 & 0.3554 & $\begin{array}{l}0.1783 \\
0.3264\end{array}$ & 0.3182 & 0.2337 & 0.1880 & GRD & \\
\hline Bingöl & 0.07 & 0.03 & 0.06 & 0.07 & 0.03 & 0.03 & 0.03 & 0.06 & 0.03 & 0.23 & 0.18 & 0.83 & 1 \\
\hline Bitlis Tatvan & 0.07 & 0.03 & 0.02 & 0.03 & 0.02 & 0.02 & 0.06 & 0.06 & 0.02 & 0.12 & 0.19 & 0.65 & 2 \\
\hline Kars Sarıkamış & 0.02 & 0.03 & 0.02 & 0.03 & 0.07 & 0.02 & 0.02 & 0.02 & 0.06 & 0.10 & 0.09 & 0.49 & 6 \\
\hline Mardin & 0.07 & 0.04 & 0.03 & 0.05 & 0.02 & 0.02 & 0.06 & 0.06 & 0.03 & 0.14 & 0.06 & 0.59 & 4 \\
\hline Şanlıurfa Siverek & 0.02 & 0.08 & 0.02 & 0.03 & 0.02 & 0.05 & 0.03 & 0.06 & 0.02 & 0.16 & 0.11 & 0.61 & 3 \\
\hline Van Erciş & 0.02 & 0.05 & 0.02 & 0.02 & 0.03 & 0.02 & 0.03 & 0.06 & 0.02 & 0.08 & 0.17 & 0.51 & 5 \\
\hline
\end{tabular}

TABle 9: Normalized decision matrix (1st officer results).

\begin{tabular}{|c|c|c|c|c|c|c|c|c|c|c|c|}
\hline & $\begin{array}{c}\text { Max } \\
\text { V type }\end{array}$ & $\begin{array}{c}\text { Max } \\
\text { V type }\end{array}$ & $\begin{array}{c}\text { Max } \\
\text { V type }\end{array}$ & $\begin{array}{c}\text { Min } \\
\text { V type }\end{array}$ & $\begin{array}{c}\text { Max } \\
\text { V type }\end{array}$ & $\begin{array}{c}\text { Min } \\
\text { V type }\end{array}$ & $\begin{array}{c}\text { Max } \\
\text { V type }\end{array}$ & $\begin{array}{c}\text { Max } \\
\text { V type }\end{array}$ & $\begin{array}{c}\text { Max } \\
\text { V type }\end{array}$ & $\begin{array}{c}\text { Max } \\
\text { V type }\end{array}$ & $\begin{array}{c}\text { Max } \\
\text { V type }\end{array}$ \\
\hline \multirow[t]{2}{*}{$\mathrm{w}$} & 0.075 & 0.076 & 0.063 & 0.069 & 0.066 & 0.051 & 0.063 & 0.058 & 0.057 & 0.234 & 0.188 \\
\hline & SC11 & SC12 & SC13 & $S C 21$ & SC22 & SC23 & SC31 & SC32 & SC33 & $C 4$ & C5 \\
\hline Bingöl & 1.00 & 0.36 & 1.00 & 1.00 & 0.45 & 0.66 & 0.33 & 1.00 & 0.60 & 1.00 & 0.98 \\
\hline Bitlis Tatvan & 1.00 & 0.00 & 0.11 & 0.29 & 0.15 & 0.01 & 1.00 & 1.00 & 0.36 & 0.53 & 1.00 \\
\hline Kars Sarıkamış & 0.00 & 0.18 & 0.00 & 0.52 & 1.00 & 0.42 & 0.00 & 0.00 & 1.00 & 0.36 & 0.47 \\
\hline Mardin & 1.00 & 0.49 & 0.33 & 0.82 & 0.04 & 0.32 & 1.00 & 1.00 & 0.60 & 0.68 & 0.00 \\
\hline Şanliurfa Siverek & 0.00 & 1.00 & 0.22 & 0.22 & 0.00 & 1.00 & 0.33 & 1.00 & 0.33 & 0.76 & 0.67 \\
\hline Van Erciş & 0.00 & 0.73 & 0.11 & 0.00 & 0.25 & 0.00 & 0.33 & 1.00 & 0.00 & 0.00 & 0.93 \\
\hline $\mathrm{p}$ & 0.25 & 0.2 & 0.2 & 0.2 & 0.01 & 0.5 & 0.25 & 0.25 & 0.2 & 0.03 & 0.02 \\
\hline$f=p-q$ & 0.25 & 0.2 & 0.2 & 0.2 & 0.01 & 0.5 & 0.25 & 0.25 & 0.2 & 0.03 & 0.02 \\
\hline $\min$ & 0 & 0 & 0 & 0 & 0 & 0 & 0 & 0 & 0 & 0 & 0 \\
\hline Max & 1 & 1 & 1 & 1 & 1 & 1 & 1 & 1 & 1 & 1 & 1 \\
\hline
\end{tabular}

TABle 10: Positive and negative advantage values, PROMETHEE I and PROMETHEE II results (1st officer results).

\begin{tabular}{|c|c|c|c|c|c|c|c|c|c|c|c|}
\hline $\begin{array}{l}\mathrm{Ct} \\
\mathrm{Pk}(\mathrm{ai}, \mathrm{aj})\end{array}$ & $\begin{array}{c}1 \\
\mathrm{a} 1\end{array}$ & $\begin{array}{c}2 \\
\mathrm{a} 2\end{array}$ & $\begin{array}{c}3 \\
\text { a3 }\end{array}$ & $\begin{array}{c}4 \\
\mathrm{a} 4\end{array}$ & $\begin{array}{c}5 \\
\mathrm{a} 5\end{array}$ & $\begin{array}{c}6 \\
\mathrm{a} 6\end{array}$ & $\phi+$ & $\mathrm{R}$ & $\phi-$ & $\phi$ net & $\mathrm{R}$ \\
\hline a1 & 0.0000 & 0.6156 & 0.8417 & 0.6469 & 0.7508 & 0.8019 & 0.7314 & 1 & 0.1354 & 0.5960 & 1 \\
\hline a2 & 0.2514 & 0.0000 & 0.6532 & 0.2537 & 0.4247 & 0.6864 & 0.4539 & 3 & 0.3975 & 0.0563 & 3 \\
\hline a3 & 0.1224 & 0.3029 & 0.0000 & 0.3210 & 0.1911 & 0.4682 & 0.2811 & 5 & 0.6577 & -0.3766 & 6 \\
\hline $\mathrm{a} 4$ & 0.1155 & 0.5306 & 0.6385 & 0.0000 & 0.3644 & 0.5933 & 0.4484 & 4 & 0.4202 & 0.0282 & 4 \\
\hline a5 & 0.1111 & 0.3964 & 0.7341 & 0.5493 & 0.0000 & 0.5219 & 0.4626 & 2 & 0.3969 & 0.0656 & 2 \\
\hline a6 & 0.0765 & 0.1421 & 0.4212 & 0.3301 & 0.2537 & 0.0000 & 0.2447 & 6 & 0.6143 & -0.3696 & 5 \\
\hline$\phi-$ & 0.1354 & 0.3975 & 0.6577 & 0.4202 & 0.3969 & 0.6143 & & & & & \\
\hline $\mathrm{R}$ & 1 & 3 & 6 & 4 & 2 & 5 & & & & & \\
\hline
\end{tabular}




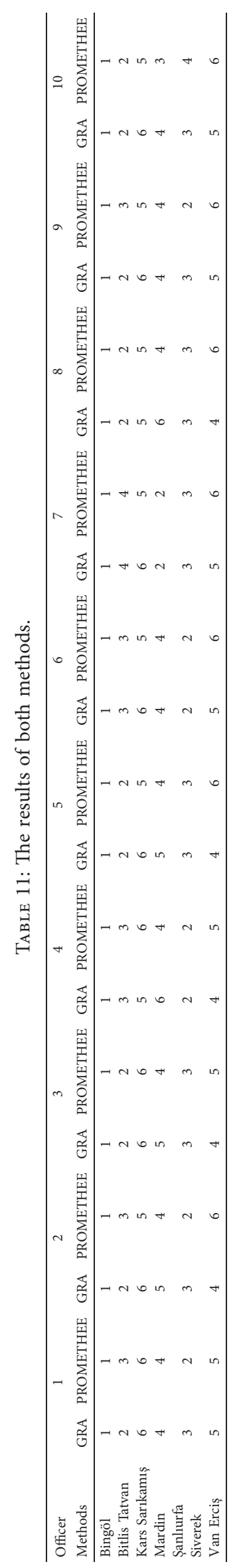


The reason for the low weight of duties and characteristics criterion is that the Turkish Armed Forces (TAF) personnel are always ready to perform any kind of duty everywhere and the TAF can perform all kinds of tasks.

4.2. Establishing the Decision Matrix. In this study, the survey was filled in by face-to-face interviews with 10 officers in the captains-major ranks and the results of the 1 st officer are shown in Table 4.

4.3. Standardization. Since the values taken by each criterion consist of different units, a standardization process was performed in the second step. The standardization of these two subcriteria was different from the others because of the better value of the smaller values in the subcriteria of the distance to the airport (SC-21) and proximity to the country (SC-23) within the transportation criterion. The standardization of SC-11, SC-12, SC-13, SC-22, SC-31, SC-32, SC-33, $\mathrm{C} 4$, and $\mathrm{C} 5$ criteria/subcriteria is given by (2) and the SC-21 and SC-23 standardization of subcriteria is done by (3).

The standardized decision matrix was created using the data in Table 4 (values obtained from the previous step). The standardized decision matrix is given in Table 5 .

4.4. Creating a Difference Matrix. The difference matrix was obtained by subtracting the reference series from the standardized decision matrix created in Table 4 to form the difference matrix. The difference matrix is shown in Table 6 . Equation (7) was used to create a difference matrix.

4.5. Calculation of Grey Relational Coefficients. The calculation of the grey relational coefficients after the calculation of the difference matrix is shown in Table 7. In the calculation of grey relational coefficients, (8) was used. $\zeta$ (ksi) value is taken as 0.5 .

4.6. Calculation of Grey Relationship Degree. It should be remembered that the calculation of the grey relationship degree is the last step of the grey relational analysis, in which the grey relational coefficients obtained in the previous stage are obtained by multiplying by the weight of the relevant criteria and gathering for each alternative. The alternative, which has the highest degree of relationship of the result of the total, is the best. Equation (9) was used to calculate the grey relation degree. Calculation of the grey relationship degree (GRD) of 1 st officer can be seen in Table 8 .

4.7. Application of PROMETHEE Method. In the study, it is observed that there are significant differences in the criteria values in the decision matrix and these values need to be normalized. We have applied the PROMETHEE method with normalized data, not raw data according to other studies $[49,50]$.

For this purpose, before starting the PROMETHEE process, the raw decision matrix was transformed into the standardized matrix obtained in the grey relational analysis, and then the PROMETHEE method was applied.

The normalized decision matrix of the first officer is shown in Table 9. Besides, weights and $p$ values of each criterion are given in the table. In the study, the type of function used is the $\mathrm{V}$ type, which is the 3rd type. For the criteria used in the study, alternatives with a value greater than a certain value were preferred. However, alternatives other than their preference and those below the specified value have not been ignored. Also, another reason for using the $\mathrm{V}$-type preferred function is that all of the values of the decision matrix are quantitative.

Following the determination of the common preference functions and preference indexes, which are the 3rd step of the PROMETHEE method, positive and negative superiority values of the first officer are calculated and shown in Table 10 .

Also, PROMETHEE I, which is the remaining step of the method, has been shown in Table 10 to obtain the partial order of alternatives to calculate the net priority values and to obtain the exact order of the alternatives with PROMETHEE II.

The results of both methods located for all officers are shown in Table 11.

\section{Conclusion}

The aim of this study is to ensure that the assignment location selections of the personnel branch officers working in the Land Forces Command are efficient and that the assignment location selections meet their needs and to determine which criterion is the most important in the selection of assignment location and to reveal preference order of the officers who make the choice. In this study, 10 officers in the personnel branch captain and major rank were interviewed face to face and the questionnaire technique was applied. The criteria used in this study were prepared by taking the opinions of 10 officers from the personnel class in the rank of colonel and sublieutenant, and five main criteria were identified. These criteria are, respectively, family situations, transportation, duty and its features, security, and social facilities. Besides, 3 subcriteria were determined for the first 3 main criteria. In the study, the weights of the criteria used according to the Max100 method were scored and the weights of the criteria were determined by taking the arithmetic means of the 10 questionnaires. The same procedure was carried out to determine the weight of the subcriteria. The main criteria vary between 0.23 and 0.18 , and no significant difference has been found between them. The safety criteria have a weight of $23 \%$, family status criteria have a weight of $21 \%$, transportation criterion has a weight of $19 \%$, the weight of social facilities criterion is $19 \%$, and the criteria of weight is $18 \%$. As the alternatives used in the study were eastern and southeastern provinces of Turkey and due to recent terror incidents, the safety criteria are higher compared to the other criteria.

The multicriteria decision-making technique used in the study was grey relational analysis and PROMETHEE methods and the places with the highest score were Bingol. Bitlis Tatvan, Sanliurfa Siverek, Van Ercis, Mardin, and Kars 
Sarıkamıs, respectively. Both methods are mutually exclusive. The results obtained in both methods are close to each other. As a result of the study, the criteria used will vary according to the weight of the place of assignment. It is expected that the importance of safety is high and the criteria of social facilities are expected to be less when the preference is made to the eastern provinces. This has been proven with this study. In the case of the choice of appointment to the provinces in the West, the weight of the security criteria will be less. In this case, family situations and social opportunities will come into prominence. The study will be based on the selection of any institution or profession in the future. The main criteria and subcriteria used in this study contain the criteria to be used in the selection of each occupation branch. However, as mentioned above, the knowledge of the scoring staff about the alternatives and the fact that they had previously lived in the area will make a significant contribution to the fact that they are more objective in scoring alternatives. Other MCDM methods can be used in future studies on this subject.

\section{Data Availability}

The data used to support the findings of this study are included in the article.

\section{Conflicts of Interest}

The authors declare no conflicts of interest.

\section{References}

[1] E. G. Turkmen, I. Gungor, and F. Erinci, "Application of analytical hierarchy process in selection of appointed teachers," International Journal of Alanya Faculty of Business, vol. 7, no. 3, pp. 35-49, 2015.

[2] E. Erciyes and C. Gencer, "Decision support systems for appointment of gendarmerie commanders in provincial gendarmerie commands," The Journal of Defence Sciences, vol. 4, no. 2, pp. 139-158, 2005.

[3] TUiK (Turkish Statistical Institute), http://www.tuik.gov.tr/ PreTablo.do?alt_id=1106.

[4] J. Thor, S.-H. Ding, and S. Kamaruddin, "Comparison of multi criteria decision making methods from the maintenance alternative selection perspective," The International Journal of Engineering and Science (IJES), vol. 2, no. 6, pp. 27-34, 2013.

[5] A. Mardani, A. Jusoh, K. MD Nor, Z. Khalifah, N. Zakwan, and A. Valipour, "Multiple criteria decision-making techniques and their applications - a review of the literature from 2000 to 2014," Economic Research-Ekonomska Istraživanja, vol. 28, no. 1, pp. 516-571, 2015.

[6] A. Soltani, K. Hewage, B. Reza, and R. Sadiq, "Multiple stakeholders in multi-criteria decision-making in the context of Municipal Solid Waste Management: a review," Waste Management, vol. 35, pp. 318-328, 2015.

[7] M. P. Basilio, V. Pereira, and H. G. Costa, "Review of the literature on multicriteria methods applied in the field of public security," Universal Journal of Management, vol. 5, no. 12, pp. 549-562, 2017.

[8] F. Sitorus, J. J. Cilliers, and R. Birito-Parada, "Multi-criteria decision making for the choice problem in mining and mineral processing: applications and trends," Expert Systems With Applications, vol. 121, pp. 393-417, 2019.

[9] B. K. Satapathy, J. Bijwe, and D. K. Kolluri, "Assessment of fiber contribution to friction material performance using grey relational analysis (GRA)," Journal of Composite Materials, vol. 40, no. 6, pp. 483-501, 2006.

[10] G. Huiand and S. Bifeng, "Study on effectiveness evaluation of weapon systems based on grey relational analysis and TOPSIS," Journal of Systems Engineering and Electronics, vol. 20, no. 1, pp. 106-111, 2009.

[11] A. I. Ozdemir and M. Deste, "Multicriteria supplier selection by grey relational analysis: a case study in automotive industry," Istanbul University Journal of the School of Business Administration, vol. 38, no. 2, pp. 147-156, 2009.

[12] I. Peker and B. Baki, "Performance evaluation in Turkish insurance sector with grey relationship analysis," International Journal of Economic and Administrative Studies, vol. 4, no. 7, pp. 1-18, 2011.

[13] E. Köse, H. S. Aplak, and M. Kabak, "Personel seçimi için gri sistem teori tabanlı bütünleşik bir yaklaşım," Ege Akademik Bakis (Ege Academic Review), vol. 13, no. 4, p. 461, 2013.

[14] B. Sisman and A. Eleren, "Selection of the most suitable car by grey relational analysis and electre methods," Süleyman Demirel University Journal of Faculty of Economics and Administrative Sciences, vol. 18, no. 3, pp. 411-429, 2013.

[15] A. Jayant, "Use of grey relational analysis in solving multiple attribute decision-making problem: a case study of warehouse location selection," Advances in Industrial Engineering and Management, vol. 4, no. 2, pp. 157-164, 2015.

[16] N. Kundakc1, "Personnel selection with grey relational analysis," Management Science Letter, vol. 6, no. 5, pp. 351360, 2016.

[17] D. Wu, N. Wang, Z. Yang, C. Li, and Y. Yang, "Comprehensive evaluation of coal-fired power units using grey relational analysis and a hybrid entropy-based weighting method," Entropy, vol. 20, no. 4, p. 215, 2018.

[18] A. Parhizgarsharif, A. Lork, and A. Telvari, "A hybrid approach based on the BWM-VIKOR and GRA for ranking facility location in construction site layout for Mehr project in Tehran," Decision Science Letters, vol. 8, no. 3, pp. 233-248, 2019.

[19] A. Albadvi, "Formulating national information technology strategies: a preference ranking model using PROMETHEE method," European Journal of Operational Research, vol. 153, no. 2, pp. 290-296, 2004.

[20] A. Albadvi, S. K. Chaharsooghi, and A. Esfahanipour, "Decision making in stock trading: an application of PROMETHEE," European Journal of Operational Research, vol. 177, no. 2, pp. 673-683, 2007.

[21] M. Beynon and P. Wells, "The lean improvement of the chemical emissions of motor vehicles based on preference ranking: a PROMETHEE uncertainty analysis," Omega, vol. 36, no. 3, pp. 384-394, 2008.

[22] C.-T. Chen, P.-F. Pai, and W.-Z. Hung, "An integrated methodology using linguistic PROMETHEE and maximum deviation method for third-party logistics supplier selection," International Journal of Computational Intelligence Systems, vol. 3, no. 4, pp. 438-451, 2010.

[23] G. C. Akkaya and E. Demireli, "PROMETHEE ordering method on financial decision process," Ege Academic Review, vol. 10, no. 3, pp. 845-854, 2010.

[24] B. Yilmaz and M. Dagdeviren, "Comparative analysis of PROMETHEE and fuzzy PROMETHEE methods in 
equipment selection problem," Gazi University Journal of Engineering and Architecture, vol. 25, no. 4, pp. 811-826, 2010.

[25] A. Ishizaka and P. Nemery, "Selecting the best statistical distribution with PROMETHEE and GAIA," Computers \& Industrial Engineering, vol. 61, no. 4, pp. 958-969, 2011.

[26] M. Soba, "Selecting the best panelvan autocar by using PROMETHEE method and an application," Journal of Yasar University, vol. 28, no. 7, pp. 4708-4721, 2012.

[27] R. Vetschera and A. T. De Almeida, "A PROMETHEE-based approach to portfolio selection problems," Computers \& Operations Research, vol. 39, no. 5, pp. 1010-1020, 2012.

[28] S. Sakarya and S. Aytekin, "Measurement of the relationship between deposit banks performance with stock returns in ISE: an application with PROMETHEE multi-criteria decision making method," International Journal of Alanya Faculty of Business, vol. 5, no. 2, pp. 99-109, 2013.

[29] K. Govindan, D. Kannan, and M. Shankar, "Evaluation of green manufacturing practices using a hybrid MCDM model combining DANP with PROMETHEE," International Journal of Production Research, vol. 53, no. 21, pp. 6344-6371, 2015.

[30] M. Bottero, C. D'Alpaos, and A. Oppio, "Multicriteria evaluation of urban regeneration processes: an application of PROMETHEE method in Northern Italy," Advances in Operations Research, vol. 2018, Article ID 9276075, 12 pages, 2018.

[31] M. Velasquez and P. T. Hester, "An analysis of multi criteria decision making methods," International Journal of Operation Research, vol. 10, no. 2, pp. 56-66, 2013.

[32] R. K. Gavade, "Multi-criteria decision making: an overview of different selection problems and methods," International Journal of Computer Science and Information Technologies, vol. 5, no. 4, pp. 5643-5646, 2014.

[33] R. E. Hodgett, "Comparison of multi-criteria decision-making methods for equipment selection," The International Journal of Advanced Manufacturing Technology, vol. 85, no. 5-8, pp. 1145-1157, 2016.

[34] P. A. Bottomley and J. R. Doyle, "A comparison of three weight elicitation methods: good, better, and best," Omega, vol. 29, no. 6, pp. 553-560, 2001.

[35] N. H. Zardari, K. Ahmed, S. M. Shirazi, and Z. Yusop, Weighting Methods and Their Effects on Multicriteria Decision Making Model Outcomes in Water Resources Management, Springer, New York, NY, USA, 2015.

[36] N. Tayyar and M. Durmuş, "Comparison of Max100, SWARA and pairwise weight elicitation methods," International Journal of Engineering Research and Applications, vol. 7, no. 02, pp. 67-78, 2017.

[37] N. Z. Ustunısık, "The socio-economic development ranking study some provinces and regions in Turkey: grey relational analysis methods and applications," M.Sc. thesis, Gazi University Graduate School of Natural and Applied Sciences, Ankara, Turkey, 2007.

[38] N. Tayyar, F. Genç, E. Genç, and I. Erem, "BİST’e Kayıtlı Bilişim ve Teknoloji Alanında Faaliyet Gösteren İşletmelerin Finansal Performanslarının Analitik Hiyerarşi Prosesi (AHP) ve Gri İlişkisel Analiz (GİA) Yöntemiyle Değerlendirilmesi,” Muhasebe Ve Finansman Dergisi, vol. 61, no. 61, pp. 19-40, 2014.

[39] L.-Y. Zhai, L.-P. Khoo, and Z.-W. Zhong, "Design concept evaluation in product development using rough sets and grey relation analysis," Expert Systems with Applications, vol. 36, no. 3, pp. 7072-7079, 2009.

[40] A. E. Yazgan and O. Karkacier, "Financial performance assessment in tourism sector with grey relationship analysis method," Selcuk University Journal of the Institute of Social Sciences, vol. 37, pp. 154-162, 2017.

[41] M. Goumos and V. Lygerou, "An extension of the PROMETHEE method for decision making in fuzzy environment: ranking of alternative energy exploitation projects," European Journal of Operational Research, vol. 123, no. 3, pp. 606-613, 2000.

[42] N. Ozguven, "Research on private shopping sites with PROMETHEEranking method," Selcuk University Journal of Social Sciences Institute, vol. 27, pp. 195-201, 2012.

[43] J.-P. Brans and B. Mareschal, Multi Criteria Decision Analysis: State of the Art Survey, PROMETHEE Methods, Springer, Boston, MA, USA, 2005.

[44] J. P. Brans and P. Vincke, "Note-A preference ranking organisation method," Management Science, vol. 31, no. 6, pp. 647-656, 1985.

[45] J. P. Brans, P. Vincke, and B. Mareschal, "How to select and how to rank projects: the PROMETHEE method," European Journal of Operational Research, vol. 24, no. 2, pp. 228-238, 1986.

[46] N. Tayyar: https://sites.google.com/site/ntayyar/skm08PROMETHEE.pdf.

[47] N. Tayyar, https://sites.google.com/site/ntayyar/skm08PROMETHEE.pdf.

[48] G. Milentijevic, B. Nedeljkovic, M. Lekic, Z. Nikic, I. Ristovic, and J. Djokic, "Application of a method for intelligent multicriteria analysis of the environmental impact of tailing ponds in Northern Kosovo and Metohija," Energies, vol. 9, no. 11, pp. 1-18, 2016.

[49] S. Yavuz and M. Deveci, "The effect of statistical normalization techniques on the performance of artificial neural network," Erciyes University Faculty of Economics and Administrative Sciences Journal, vol. 40, pp. 167-187, 2012.

[50] O. Sungur and S. I. Maden, "Ranking of manufacturing industry sectors in TR61 region (Antalya, Isparta, Burdur) with PROMETHEE method," Ege Academic Review, vol. 16, no. 4, pp. 641-654, 2016. 